\title{
The Study of Growth and Its Polyembryonic Properties of Porang Seeds (Amorphophallus muelleri Blume) from Various Fruit Colors in Different Planting Media
}

\author{
Imaniah Bazlina Wardani ${ }^{1}$, Nunung Harijati ${ }^{2}$, Retno Mastuti ${ }^{2}$ \\ ${ }^{1}$ Master Program in Biology, Faculty of Mathematics and Natural Sciences, University of Brawijaya, Malang, Indonesia. \\ 2Department of Biology, Faculty of Mathematics and Natural Sciences, University of Brawijaya, Malang, Indonesia
}

\begin{abstract}
The ripening of Porang compound fruit (Amorphophallus muelleri Blume) in one cob does not occur simultaneously but moves forward from the distal region to proximal. The ripe fruit is red, almost ripe is yellow and unripe is green. The study aimed to examine the growth potential and polyembryonic properties of Porang seeds derived from red, yellow and green fruits. These seeds were grown in different media with the expectation the best plant growth can be obtained. This research was a factorial experiment which was arranged in a completely random design and each unit observation has three replication. The factor I was the source of seeds. Seeds came from various fruit colors. Each of them is red $(R)$, yellow $(Y)$ and green $(G)$. Factor II is a planting medium which had 4 types, $M 1, M 2, M 3$, and $M 4$. M1 is combination of soil and husk charcoal (70\%: $30 \%), \mathrm{M} 2=$ soil: cocopeat $(70 \%: 30 \%), \mathrm{M} 3=$ soil: husk charcoal: cocopeat (70\%: $15 \%: 15 \%)$ and M4 = just soil (100\%). The results showed that the seeds derived from red fruit and planted on medium 2 (soil: cocopeat $=70 \%: 25 \%$ ) potentially producing the best plant. The seeds also showed $100 \%$ polyembryony at 182 days after planting. In addition, the first, second and third shoots (originating from one seed) have different in height, canopy diameters, and petiole diameter.
\end{abstract}

Keywords: Fruitcolors, planting media, polyembriony, Porang (Amorphophallus muelleri Blume).

\section{INTRODUCTION}

Amorphohallus muelleri is a tuber plant of the family Araceae. In Indonesia, this plant is called Porang. A. muelleri contains high glucomannan. Glucomannan is widely used as a food, diet controller, cosmetics and industry [1].

The high benefits of $A$. muelleri cause an increasing demand of it from several countries such as Japan, Hong Kong, and Australia. However, production of $A$. muelleri in Indonesia, has not been able to meet this demand. The production of chips $A$. muelleri in East Java is around $600 \mathrm{~kg}-1,000$ tons, while industrial demand reaches 3,400 tons of chips [2]. Therefore, land expansion is needed and sufficiency of planting material is to be considered.

Planting material of $A$. muelleri can be obtained from tubers, bulbs and seeds. The popular one, people use tuber as planting material. In 1 hectare land area, the seeds planted from the bulbil $\pm 170-175$ pieces and tubers $\pm 20-20$ pieces while from the seeds can be more than \pm 900 grains so that the seeds are considered the most efficient as planting material [3]. Based on observations in the porang garden

\footnotetext{
*Correspondence address:

Imaniah Bazlina Wardani

Email : imaniahbazlinawardani@gmail.com

Address : Dept. Biology, University of Brawijaya, Veteran Malang 65145.
}

Rejosari Village, District Bantur Malang, that the availability of seeds is also plenty, that in every plant A. muelleri can be produced $\pm 600-800$ seeds (compounds fruit).

Germination and growth of seeds depend on the quality of the seeds. Good seeds are harvested when in the period of physiological ripe [4]. Physiological ripe time of seeds can be known through the fruit ripening, because the ripe time of seeds and fruit occurred together [5]. In previous studies, it was also reported that fruits harvested at physiological ripe produce high quality seeds in term of viability and vigority [6]. Ripening of fruit can be identified by changes in skin color of the fruit [7]. Therefore fruit skin color, in general, may be used to determine the age of seeds in it. In A. muelleri, based on empirical observations, the red color of fruit skin as indicator of fruit ripening does not occur simultaneously. Often found in the field, in one cob of $A$. muelleri has three fruit colors. Red in the distal area, then in the proximal direction there appears a group of yellow and green fruit.

The level of fruit maturity also affects the level of maturity of the seeds and the ability to germinate. The ripe fruit will be followed by the maturity of the seeds in it. Seeds that are harvested when physiologically matured contain enough nutrients (carbohydrates, complex fats, and proteins) to germinate optimally. However, the immature seeds contain no maximum 
nutrients [8]. In addition, the planting media also affects seed growth, where the composition of the appropriate planting media can support seed growth [9].

Seeds of A. muelleri have polyembryony properties, wherein one seed has more than one embryo. This is an advantage that can be utilized in the development of A. muelleri through seeds [3]. This study aims to determine the potential of seeds from various fruit colors (red, yellow, green) and the effect of the composition of the planting medium used on the growth of $A$. muelleri. In addition, the characteristics of the polyembryonic properties of A. muelleri seeds were also examined.

\section{MATERIAL AND METHOD}

\section{Sampling of Porang Fruit}

Samples used in this study were obtained from Rejosari Village, Bantur District, Malang Regency. The sample is porang fruit which has a different color on one cob which is red in distal region, yellow in the middle and green at the base/proximal parts (Fig. 1). The difference in the color of the fruit is used as a mark of different seed ages.

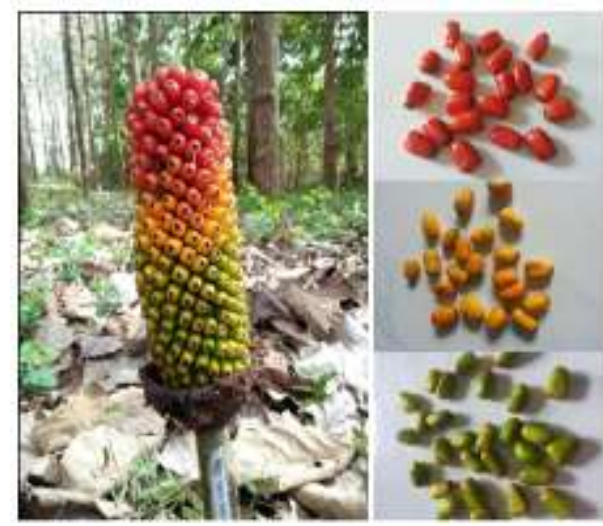

Figure 1. Porang Fruit Samples with Variations Skin Color

\section{Preparation of Seed}

Seeds are obtained from Porang fruit which was grouped according to the fruit skin color (green, yellow and red). Porang fruits from each color group were peeled to get seeds, then the seeds were washed and dried. The seeds used were seeds with relatively the same size, healthy and not moldy.

\section{Media Planting Preparation}

The media used for this study consisted of 4 types of planting media compositions named M1, M2, M3, and M4 (Table 1). All media were firstly steamed for 15 minutes and then dried.
Furthermore, soil, cocopeat, and husk charcoal were weighed according to the composition in the treatment and mixed well. Then 80 grams of media were loaded into $5 \times 15 \mathrm{~cm}$ polybags.

Table 1. Composition of Planting Media

\begin{tabular}{cc}
\hline Media Type & Composition (\%) \\
\hline Media 1 & Soil 70 + husk charcoal 30 \\
Media 2 & Soil $70+$ Cocopeat 30 \\
Media 3 & Soil 70+ husk charcoal15+ Cocopeat 15 \\
Media 4 & Soil 100 \\
\hline
\end{tabular}

\section{Seeds Planting}

The seeds that have been grouped based on the color of the fruit skin were planted on a planting media according to treatment (M1-M4). Each treatment $(\mathrm{M})$ consisted of 15 polybags and each treatment had 3 replications. Therefore, the total polybags of each treatment was 45 .

\section{Parameters of Growth and Germination}

The observed parameters consisted of germination and growth parameters. Germination parameters included :

a) Time of shoot emergence, namely the time needed to bring out the first shoot;

b) Germination percentage. It was calculated 130 days after planting (DAP). Germination rate used formula as below:

Germination $\%=\frac{\text { number of seed that germinate }}{\text { number of seeds planted }} \times 100 \%$

c) Number days (DAP) which was required to reach $60 \%$ seed germinated (uniformity of germination)

While the growth parameters included:

a) Petiole height. It was measured from the ground to the base of the lamina.

b) Petiole diamater. It was measured using digital calipers in $1 \mathrm{~cm}$ above the ground.

c) Canopy diameter. It was measured from one end of the canopy to the opposite end of the canopy

\section{Data Analysis}

This research was organizedusing completely randomized design (CRD) of two factors, namely the fruit color (consisting of 3 levels) and the planting medium (consisting of 4 levels). The obtained data from both the germination and growth data were analyzed using ANOVA, if the effect of fruit color and real planting media were significant, the analysed will be continued by theTukey test with a $5 \%$ significance level. 


\section{RESULTS AND DISCUSSION}

\section{The Germination of $A$. muelleri Blume}

The results of the ANOVA test showed that the time of shoot emergence was significantly influenced by the interaction between seeds from different fruit colors and planting media. Seeds from red fruit planted in M3 media (soil, husk charcoal, and cocopeat) produced the first shoots earliest, i.e. at 70 days after planting (Table 2).

Table 2. The time that was required by shoot of $A$. muelleri to $1^{\text {st }}$ emerged from red, yellow, and green seeds which grow in various medium

\begin{tabular}{lll}
\hline \multicolumn{2}{l}{ Fruit Color } & \multicolumn{1}{c}{ Time of shoot emergence (DAP) } \\
\hline \multirow{4}{*}{ Red } & M1 & $87.00 \pm 0.01 \mathrm{~b}$ \\
& M2 & $94.00 \pm 7.55 \mathrm{bc}$ \\
& M3 & $70.33 \pm 0.57 \mathrm{a}$ \\
& M4 & $86.67 \pm 6.42 \mathrm{~b}$ \\
\hline \multirow{4}{*}{ Yellow } & M1 & $103.33 \pm 1.15 \mathrm{cde}$ \\
& M2 & $85.33 \pm 2.88 \mathrm{~b}$ \\
& M3 & $100.33 \pm 0.57 \mathrm{~cd}$ \\
Green & M4 & $108.67 \pm 4.04 \mathrm{de}$ \\
\hline \multirow{4}{*}{ M1 } & $115.00 \pm 6.92 \mathrm{e}$ \\
& M3 & $111.00 \pm 3.46 \mathrm{de}$ \\
& M4 & $110.00 \pm 1.00 \mathrm{de}$ \\
\hline
\end{tabular}

Notes: $\mathrm{M} 1$ = soil and husk charcoal (70\%: 30\%), $\mathrm{M} 2$ = soil: cocopeat (70\%: 30\%), M3 = soil: husk charcoal: cocopeat (70\%: $15 \%$ : $15 \%$ ) and M4 = just soil (100\%). ${ }^{*}$ ) for all rows of numbers followed by the same letters, it was not significantly different based on Tukey test $\alpha 0.05$.

Table 2 showed that in addition to the level of maturity of seeds, planting media type also gave effect to the time of the emergence of the first shoots. Soil, husk charcoal, and cocopeat (M3) were the media components that gave the best results in this parameter. This mixture can create loose and moist of media. Media moisture is supported by cocopeat, because of its ability to bind and store water strongly [10]. Humidity is also needed in the initial phase of germination, because seeds need water before germination.

The loose of media was allegedly due to the presence of husk charcoal. Characteristics of husk charcoal are to reduce the density of the media therefore the plant roots easily penetrate the media [11]. In addition to the roots, loose media will also make the plumula penetrate the surface of the growing media smoothly. The appearance of plumula to the surface of the growing media is a sign that $A$. muelleri seeds are beginning to sprout.

In contrast with the time of shoot emergence, percentage germination at 130 DAP was only affected by the fruit color. Based on Tukey's test, the seeds are derived from red fruit has the highest percentage germination i.e. $92 \% \pm 7.71$. Then followed by seeds from yellow fruit i.e. $64.5 \% \pm 5.86$ and the lowest seed from green fruit i.e. $37.77 \% \pm 8.20$ (Table 3 )

Table 3. The Effect of fruit colors on percentage germination at $130 \mathrm{DAP}$

\begin{tabular}{cc}
\hline Fruit Color & Percentage Germination (\%) \\
\hline Red & $92.09 \pm 7.71 \mathrm{c}$ \\
Yellow & $64.50 \pm 5.86 \mathrm{~b}$ \\
Green & $37.77 \pm 8.20 \mathrm{a}$ \\
\hline
\end{tabular}

Notes: for all rows of numbers followed by the same letters, it was not significantly different based on Tukey test $\alpha 0.05$

These results showed that red seed gave the highest germination (92\%) at 130 DAP. Yellow and green seeds were following. The germination rate increased with the level of fruit maturity. In this study, the level of maturity is indicated by the color of the fruit (red, yellow and green). In research of cayenne pepper varieties, Rama also reported that germination rate of chili seed reaches a maximum when physiologically mature and will decrease when it has passed the physiologically mature [12].

The next parameter is the uniformity of germination. Every seed that has a $1 \mathrm{~cm}$ plumule on the surface of the media was considered to be germinated. The results of the ANOVA test showed that the uniformity of germination was significantly affected by the interaction between seeds from different fruit colors and planting media. Based on Tukey test it can be seen that treatment RM3 seeds of red-skinned fruit that are grown in medium 3 (a mixture of soil, rice husk, and cocopeat) had the shortest time to the emergence of shoots up to $60 \%$ compared to other treatment that is 92 DAP (Table 4). This result is the same as the time of the first shoots. Therefore, in this study, the seeds that were able to produce the first shoots also had the shortest time in raising shoots up to $60 \%$.

The results showed that the seeds of yellow and green-skinned fruit at the time of harvesting have not entered physiological maturity. So that uniformity of germination is lower, and the time for the first shoots to emerge and the $60 \%$ germination are longer than the seeds of the redskinned fruit. The seeds that are harvested before reaching mature physiology, food reserve stored in the seed embryo is insufficient and not fully formed [13]. Previous studies also reported that Cayenne (Capsicum frutescent L.) seeds with 
different levels of maturity had a significant effect on seed germination (\%) and seed germination rate[14].

Table 4 . The time that was required by shoot of $A$. muellerito $60 \%$ germination from red-, yellow-, and green seeds which grow in various medium

\begin{tabular}{cll}
\hline \multicolumn{2}{c}{ Treatment } & \multicolumn{1}{c}{$\begin{array}{c}\text { Uniformity of germination } \\
\text { (DAP) }\end{array}$} \\
\hline Red & M1 & $99.33 \pm 2.30 \mathrm{ab}$ \\
(R) & M2 & $114.00 \pm 11.53 \mathrm{bcd}$ \\
& M3 & $92.33 \pm 2.88 \mathrm{a}$ \\
& M4 & $114.67 \pm 5.68 \mathrm{bcd}$ \\
\hline Yellow & M1 & $125.33 \pm 4.04 \mathrm{cde}$ \\
(Y) & M2 & $109.33 \pm 5.50 \mathrm{bc}$ \\
& M3 & $128.33 \pm 1.15 \mathrm{cde}$ \\
& M4 & $133.33 \pm 3.05 \mathrm{ef}$ \\
\hline Green & M1 & $132.33 \pm 7.23 \mathrm{ef}$ \\
(G) & M2 & $143.33 \pm 7.23 \mathrm{f}$ \\
& M3 & $142.67 \pm 6.02 \mathrm{f}$ \\
& M4 & $139.33 \pm 1.52 \mathrm{ef}$
\end{tabular}

Notes: M1 = soil and husk charcoal (70\%: 30\%), M2 = soil: cocopeat (70\%: 30\%), M3 = soil: husk charcoal: cocopeat (70\%: $15 \%$ : $15 \%$ ) and M4 = just soil (100\%). ${ }^{*}$ ) for all rows of numbers followed by the same letters, it was not significantly different based on Tukey test $\alpha 0.05$

\section{The Growth ofAmorphohallus muelleri Blume}

The ANOVA results showed that seedling growth (height and diameter of petiole and canopy) was significantly affected by the interaction between fruit color and planting media. Based on the Tukey test, the treatment that showed the best results on the growth of $A$. muelleri was the treatment of RM2, seed from red fruit planted in soil and cocopeat media. The treatment was able to produce the best seeds, was higher seedlings, larger petiole diameter, and wider canopy diameter compared to the other treatments (Figure 2).

The seeds of the red fruit are thought to have entered physiological maturity. So that the availability of food reserves in these seeds is sufficient to be used to grow compared with both yellow and green seeds. Food reserves sufficient seed to accelerate the growth of shoots and roots. When shoots and roots grow faster, the growth of these plants will be faster too [15].

In addition to the level of seed maturity, seedling growth is also influenced by the planting media. In this study, media 2 which is a mixture of soil media with cocopeat is the best media to support the growth of $A$. muelleri seedlings. Cocopeat is a medium that has a high water holding capacity which reaches 14.71 times its dry weight [16]. In the previous study, it was also stated that cocopeat was able to improve the physical properties of soil, which made the soil have good drainage so that it supports root development. When the plant roots are well developed, the absorption of nutrients will be optimal. These conditions can support plant growth. Similarly, in sengon laut (Paraserianthes falcataria) plants where planting using soil and cocopeat growing media gave the best results on the parameters of height increase, the diameter of the petiole and the number of leaves [17].
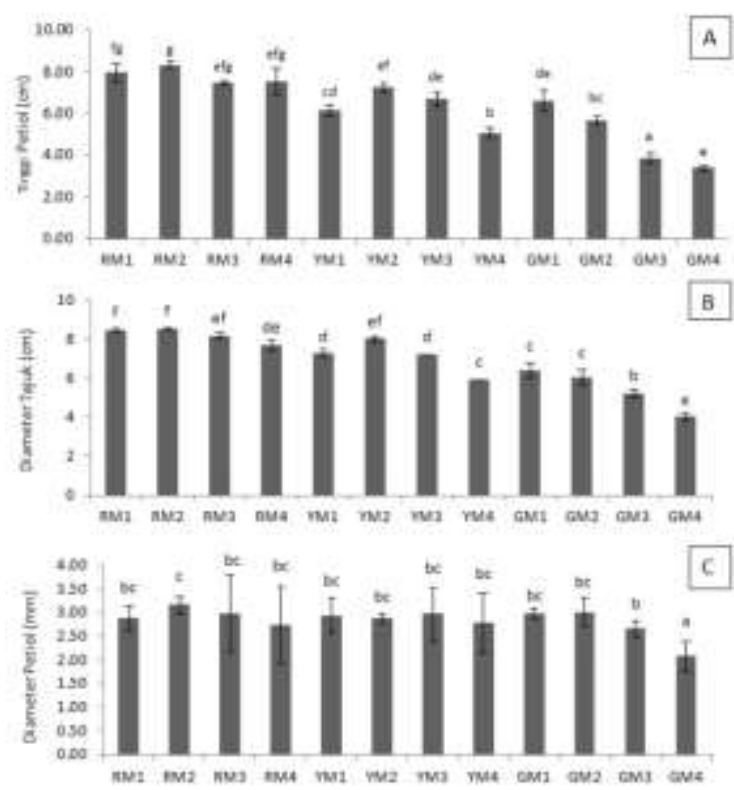

Figure 2. Interaction between Fruit Colors and Planting Media on Growth of A. muelleri. At 154 day after planting, A. petiole height, B. diameter of canopy C. diameter of petiole $R=$ Seeds of red fruit, $Y=$ Seeds of yellow fruit, $G=$ Seeds of green fruit, $M=$ planting medium. $\mathrm{M} 1=$ soil and husk charcoal (70\%: $30 \%)$, M2 = soil: cocopeat (70\%: 30\%), M3 = soil: husk charcoal: cocopeat (70\%: 15\%: 15\%) and M4 = just soil (100\%).

\section{Polyembryonic Properties of Amorphohallus muelleri Blume}

Previous studies related to the germination of porang seeds, stated that in $A$. muelleri polyembryonic phenomenon was found. It is the occurrence of more than one embryo in one seed [18]. In this study, polyembryony plants were found as well (Fig. 3). Shoots produced from polyembryony seed was varied, there are 2 shoots (Fig. 3A), 3 shoots (Fig. 3B) and 4 shoots (Fig. 3C) at 182 days after planting.

The seeds of the red fruit all show polyembryonic properties, produce 2 to 4 shoots. However, the seeds of the yellow fruit, besides produce one shoot (monoembryony) also produce 2, 3 and 4 shoots (polyembryony) in all types of planting media. Production of 4 shoots 
from yellow seeds was lower than red seed. While seeds from green fruit are monoembryony and polyembryony ( 3 shoots) which grow in all growing media. Polyembryo seeds with three shoots only on media M3 (Table 5).
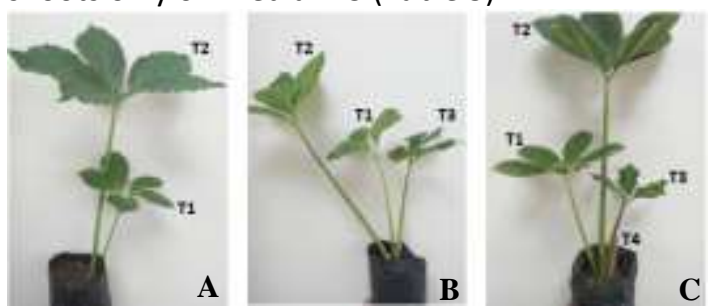

Figure 3. Plant $A$. Muelleri in 182 days after planting. A. Polyembriony plants with 2 shoots

B. Polyembryonic plants with 3 shoots

C. Polyembryonic plants with 4 shoots

Table 5. Percentage number of shoot on A. Muelleri

\begin{tabular}{|c|c|c|c|c|c|}
\hline \multirow[t]{2}{*}{ Seeds type } & \multirow{2}{*}{$\begin{array}{l}\text { Planting } \\
\text { media }\end{array}$} & \multicolumn{4}{|c|}{$\begin{array}{l}\text { Seed with variation } \\
\text { number of shoot (\%) }\end{array}$} \\
\hline & & 1 & 2 & 3 & 4 \\
\hline \multirow{4}{*}{$\begin{array}{l}\text { Seeds from } \\
\text { red fruit }\end{array}$} & M1 & 0 & 6 & 74 & 20 \\
\hline & $\mathrm{M} 2$ & 0 & 30 & 67 & 3 \\
\hline & M3 & 0 & 30 & 67 & 3 \\
\hline & M4 & 0 & 17 & 53 & 30 \\
\hline \multirow{4}{*}{$\begin{array}{l}\text { Seeds from } \\
\text { yellow fruit }\end{array}$} & M1 & 7 & 53 & 40 & 0 \\
\hline & M2 & 33 & 40 & 20 & 7 \\
\hline & M3 & 20 & 73 & 7 & 0 \\
\hline & M4 & 80 & 20 & 0 & 0 \\
\hline \multirow{4}{*}{$\begin{array}{l}\text { Seeds from } \\
\text { green fruit }\end{array}$} & M1 & 7 & 93 & 0 & 0 \\
\hline & M2 & 64 & 46 & 0 & 0 \\
\hline & M3 & 40 & 20 & 20 & 0 \\
\hline & M4 & 80 & 20 & 0 & 0 \\
\hline
\end{tabular}

Notes: M1 = soil and husk charcoal (70\%: 30\%), M2 = soil: cocopeat $(70 \%$ : 30\%), M3 = soil: husk charcoal: cocopeat (70\%: 15\%: $15 \%)$ and $M 4=$ just soil $(100 \%)$.

In this study, the first, second and third shoots that appear in one seed have different morphological characteristics (petiole, canopy diameter, and petiole). It was observed that the first shoots had an average height of $7.54 \mathrm{~cm}$, the second shoots had a height of $14.7 \mathrm{~cm}$ (twice the height of the first shoot), the third shoots were $8.41 \mathrm{~cm}$ which was not significantly different from the first shoots and the fourth shoots not yet emerge leaves and petiole at 196 days after planting (Table 6).

Table 6. The Growth of polyembryonic shoots in red fruit A. muelleri 196 days after Planting

\begin{tabular}{cccc}
\hline $\begin{array}{c}\text { Type } \\
\text { Shoot }\end{array}$ & $\begin{array}{c}\text { Petiole } \\
\text { Height }(\mathbf{c m})\end{array}$ & $\begin{array}{c}\text { Canopydiameter } \\
(\mathbf{c m})\end{array}$ & $\begin{array}{c}\text { Petiole } \\
\text { diameter } \\
(\mathbf{m m})\end{array}$ \\
\hline $1^{\text {st }}$ & $7.54 \pm 10.01 \mathrm{a}$ & $8.25 \pm 1.37 \mathrm{a}$ & $2.93 \pm 0.37 \mathrm{a}$ \\
$2^{\text {nd }}$ & $14.7 \pm 3.34 \mathrm{~b}$ & $12.7 \pm 2.86 \mathrm{~b}$ & $4.53 \pm 0.72 \mathrm{~b}$ \\
$3^{\text {rd }}$ & $8.41 \pm 1.60 \mathrm{a}$ & $8.41 \pm 1.56 \mathrm{a}$ & $3.09 \pm 0.39 \mathrm{a}$ \\
\hline
\end{tabular}

Notes: for all rows of numbers followed by the same letters, it was not significantly differen based on Tukey test $\alpha 0.05$ in each parameter
At observations 204 days after planting, the first shoots begin to turn yellow and then wither at 210 days after planting. While the second, third and fourth shoots are still growing. At the end of the growth the second to fourth shoot have height petiol, canopy diameter and petiol diameter was not significantly different and larger than the first shoot (Table 6).

Tabel 6. Growth of Polyembryonic Shoots $A$. muelleri in 196-220 days after Planting

\begin{tabular}{cccc}
\hline $\begin{array}{c}\text { Type } \\
\text { Shoot }\end{array}$ & $\begin{array}{c}\text { Petiole Height } \\
(\mathbf{c m})\end{array}$ & $\begin{array}{c}\text { Canopy } \\
\text { diameter }(\mathbf{c m})\end{array}$ & $\begin{array}{c}\text { Petiole } \\
\text { diameter } \\
(\mathbf{m m})\end{array}$ \\
\hline $1^{\text {st }}$ & $7.54 \pm 10.01 \mathrm{a}$ & $8.25 \pm 1.37 \mathrm{a}$ & $2.93 \pm 0.37 \mathrm{a}$ \\
$2^{\text {nd }}$ & $14.70 \pm 1.79 \mathrm{~b}$ & $13.69 \pm 1.90 \mathrm{~b}$ & $4.35 \pm 0.52 \mathrm{~b}$ \\
$3^{\text {rd }}$ & $14.44 \pm 1.90 \mathrm{~b}$ & $13.03 \pm 1.14 \mathrm{~b}$ & $5.04 \pm 0.49 \mathrm{~b}$ \\
$4^{\text {th }}$ & $14.74 \pm 4.23 \mathrm{~b}$ & $12.70 \pm 2.51 \mathrm{~b}$ & $4.07 \pm 0.72 \mathrm{~b}$ \\
\hline
\end{tabular}

Notes: for all rows of numbers followed by the same letters, it was not significantly differen based on Tukey test $\alpha 0.05$ in each parameter

Polyembryo plants have more than one embryo in one seed. So that the different characteristics of the first, second and third shoots in $A$. muelleri can be possible because all three grow from different embryos in the same seed.

In the study of mangosteen fruit which is also polyembryonic, it is stated that from each bud that emerges from the same seed carries a different genetic constitution [18]. another study it was found that four of the nine polyembryonic mangosteen seeds showed differences in DNA bands in shoots that grew from the same seed [19]. This may cause differences in morphological characters between the first, second and third shoots in the same seed.

\section{CONCLUSION}

The RM3 treatment show the best results for germination, but RM2 treatment produces the best for seed and plant growth. A. muelleri at various level of ripening indicates the presence of polyembrionic seeds with variation on the number of shoots, where the first shoots are no larger than the second up to fourth seeds.

\section{REFERENCES}

[1] Zhang, Y.Q., B.J. Xie, X. Gan. 2005. Advance in the applications of konjac glucomannan and its derivatives. Carbohyd. Polym. 60. 27-31

[2] Suheriyanto, D., Romaidi, R.S. Resmisari. 2012. Pengembangan bibit unggul Porang (Amorphophallus muelleri Blume.) melaui teknik kultur In Vitro untuk mendukung 
ketahanan pangan nasional. El-Hayah. 3(1). 16-23.

[3] Penelitian dan Pengembangan Porang Indonesia Universitas Brawijaya. 2013. Budidaya dan pengembangan Porang (Amorphophallus Muelleri Blume) sebagai salah satu potensi bahan baku lokal. University of Brawijaya Press. Malang.

[4] Ashworth, S. 2002. Seed to seed: seed saving and growing techniques for vegetable gardeners. Seed Savers Exchange, Inc., lowa.

[5] Kamil, J. 1979. Tekonologi benih 1. Angkasa Raya. Padang.

[6] Ahmed, A.M. Shamsheer, S. Tirakannavar, M.N. Merwade, P.M. Gangadarappa, V. Devappa. 2008. Influence of stages of fruit harvest and post harvest ripening periods on seed quality in paprika chili (Capsicum annuum L.). Karnataka J. Agric. Sci. 21(2). 266-269.

[7] Charoenchongsuk, N., D. Matsumoto, A. Itai, H. Murayama. 2018. Ripening characteristics and pigment changes in russeted pear fruit in response to ethylene and 1-MCP. Horticulturae. 4(22). 2-14

[8] Hartman, H.T., D.E. Kester, F.T. Davies, R.L. Geneve. 1997. Plant propagation principles and practices, $3^{\text {rd }}$ Ed. Prentice-Hall. Engglewood Clifft.

[9] Ilyas, Y., J.A. Rombang, Marthen, T. Lasut, E.F.S. Pangemanan. 2015. Pengaruh media tanam terhadap pertumbuhan bibit Jabon merah (Anthocephalus macrophyllus (Roxb) Havil). Faculty of Agriculture, Sam Ratulangi University. Indonesia.

[10] Irawan, A., K. Yeremias. 2015. Pemanfaatan cocopeat dan arang sekam padi sebagai media tanam bibit cempaka wasian (Elmerrilia ovalis). Proceeding of National Seminar of Indonesia Biodiversity Community. 1(4). 805-808

[11] Agustin, D.A., M. Riniarti, Duryat. 2014. Pemanfaatan limbah serbuk gergaji dan arang sekam sebagai media sapih untuk Cempaka Kuning (Michelia champaca). Jurnal Sylva Lestari. 2(3). 49-58.

[12] Sinuraya, F. 2007. Indikator karotenoid untuk menentukan masak fisiologi benih cabai rawit (Capsicum frutescens L.) varietas Sulawesi dan Rama. Bachelor Thesis. Faculty of Agriculture, Bogor Agricultural University. Bogor.

[13] Sutopo, L. 2002. Teknologi benih. Rajawali. Jakarta.
[14] Darmawan, A.C., Respatijarti, L. Soetopo. 2013. Effect of seed maturity on growth and productions of hot pepper (Capsicum frutescent L.) on Comexio variety. Jurnal Produksi Tanaman. 2(4). 339-346

[15] Sumarwoto, 2004. Pengaruh pemberian kapur dan ukuran bulbil terhadap pertumbuhan lles-iles (Amorphophallus muelleri Blume) pada tanah ber AL tinggi. Ilmu Pertanian. (Agr. Sci.). 11(2): 45-55

[16] Ramadhan, D., M. Riniart, S. Trio. 2018. Pemanfaatan cocopeat sebagai media tumbuh sengon laut (Paraserianthes falcataria) dan Merbabu Darat (Intsia palembanica). Jurnal Sylva Lestari. 6(2). 2231.

[17] Gusmalawati, D. 2013. Struktur perkembangan organ generative dan daya tumbuh biji Porang (Amorphophallus muelleri). Master Thesis. Department of Biology, University of Brawijaya. Malang.

[18] Widiastuti, A., 2010. Analisis keragaman genetik manggis (Garcinia mangostana L.) hasil iradiasi sinar gamma berdasarkan morfologi, anatomi, dan penanda ISSR. Master Thesis. Bogor Agricultural University. Bogor.

[19] Mansyah, E., M.J. Anwarudinsyah, L. Sadwiyanti, A. Susilohadi. 1999. Variabilitas genetic tanaman manggis melalui analisis isozim dan kaitannya dengan variabilitas fenotiknya. Zuriat. 10(1). 1-9. 